\title{
Validation of a Non-Targeted LC-MS Approach for Identifying Ancient Proteins: Method Development on Bone to Improve Artifact Residue Analysis
}

Andrew Barker ${ }^{1 *}$, Jonathan Dombrosky ${ }^{2}$, Dale Chaput ${ }^{3}$, Barney Venables ${ }^{1}$, Steve Wolverton ${ }^{4}$, and Stanley M. Stevens ${ }^{3}$

Author Addrersses: ${ }^{1}$ Department of Biological Sciences, University of North Texas, 1155 Union Circle \#305220, Denton, TX 76203, USA. ${ }^{2}$ Department of Anthropology, University of New Mexico, MSC01-1040, Anthropology 1, Albuquerque, NM 87131, USA. ${ }^{3}$ Department of Cell Biology, Microbiology and Molecular Biology, University of South Florida, 4202 East Fowler Ave, ISA2015, Tampa, FL 33620, USA. ${ }^{4}$ Department of Geography, University of North Texas, 1155 Union Circle \#305279, Denton, TX 76203, USA.

*Corresponding author: AndrewBarker@my.unt.edu

Received: December 2, 2014

Volume: 6(1):162-174

Published: September 4, 2015

(C) 2015 Society of Ethnobiology

Abstract: Identification of protein residues from prehistoric cooking pottery using mass spectrometry is challenging because proteins are removed from original tissues, are degraded from cooking, may be poorly preserved due to diagenesis, and occur in a palimpsest of exogenous soil proteins. In contrast, bone proteins are abundant and well preserved. This research is part of a larger method-development project for innovation and improvement of liquid chromatography - mass spectrometry analysis of protein residues from cooking pottery; here we validate the potential of our extraction and characterization approach via application to ancient bone proteins. Because of its preservation potential for proteins and given that our approach is destructive, ancient bone identified via skeletal morphology represents an appropriate verification target. Proteins were identified from zooarchaeological turkey (Meleagris gallopavo Linnaeus Phasianidae), rabbit (Lagomorpha), and squirrel (Sciuridae) remains excavated from ancient pueblo archaeological sites in southwestern Colorado using a nontargeted LC-MS/MS approach. The data have been deposited to the ProteomeXchange Consortium with the dataset identifier PXD002440. Improvement of highly sensitive targeted LC-MS/MS approaches is an avenue for future method development related to the study of protein residues from artifacts such as stone tools and pottery.

Keywords: Archaeological chemistry, Bone protein residues, Ancient proteins, Mass spectrometry

Introduction

Mass spectrometry is a commonly used approach for identifying ancient proteins (e.g., Mikšik et al. 2014; Warinner et al. 2014). Analysis of ancient bone proteins has witnessed substantial advancement during the last decade (see Buckley and Wadsworth 2014; Cappellini et al. 2014; Welker et al. 2015), some of which can be attributed to the peptide fingerprinting methodology, ZooMS, (Buckley et al. 2009; 2010, 2014; van Doorn et al. 2011) but which also relates to the general applicability of high throughput MS to bone (Cappellini et al. 2012, 2014). In contrast, MS analysis of ancient protein residues from artifacts for the study of past subsistence has lagged (Barker et al. 2012, Barnard 2007; but see Heaton et al. 2009; Solazzo et al. 2008). To address this deficiency, our paper focuses on the analysis of bone proteins using the extraction methodology of Barker et al. (2012;
Stevens et al. 2010) and a non-targeted liquid chromatography-mass spectrometry (LC-MS) analysis to identify proteins in zooarchaeological bone from the American Southwest. The results represent an important stepping stone in our research trajectory, in which we are moving from the recovery and identification of relatively well-preserved archaeological bone proteins to the analysis of, in comparison, poorly understood, poorly preserved, and lower-abundance archaeological protein residues from ceramic artifacts.

Although identification of bone proteins using mass spectrometry is common (see Buckley and Wadsworth 2014; Cappellini et al. 2014; Welker et al. 2015), our results are important for three reasons. First, they validate our methodology. While we have previously reported individual identifications made as part of method development (Barker 2011, Wolverton et al. 2014), this study represents the first comprehen- 
sive evaluation of our methodology as applied to multiple taxa to identify ancient proteins from several sites. In contrast to bone proteins, which are protected in bone tissue and primarily derive from a single taxonomic origin, artifact protein residues are removed from original matrices, are likely to represent complex taxonomic input, and have potentially been modified and damaged to an unknown degree via cooking and other taphonomic processes. As a result, protein residues from such artifacts occur in trace quantities if they preserve, and, relative to bone, are likely to be composed of taxonomically diverse and less predictable mixtures. By analyzing bone identifiable to particular taxonomic groups using traditional zooarchaeological analysis (Driver 1992, 2011; Wolverton 2013), rather than residues from ceramics, we minimize these challenges such that we are able to efficiently validate our approach, which is ultimately tailored for the non-targeted analysis of taxonomically diverse mixtures. Second, we analyze proteins from zooarchaeological bone excavated from contexts similar in age and location to those from which we seek to identify protein residues from archaeological cooking pottery. Though this provides no guarantee of protein survival in associated ceramics, it confirms the potential for protein survival in this general context (southwestern Colorado) and provides insight into the types of diagenetic processes that have occurred. Finally, it is unethical to destroy cooking pottery artifacts for purposes of method development when we are certain that our approach can be verified through analysis of commonly recovered zooarchaeological bone that can be identified using skeletal morphology.

This paper records the second stage of our method development process, which began with optimizing an extraction protocol (Barker et al. 2012). Here, this protocol is verified for application to ancient proteins from a tissue with high preservation potential (bone). Subsequent applications of this approach will employ targeted LC-MS approaches that characterize trace quantities of artifact protein residues from experimental and archaeological contexts. This section is followed by a brief comparison of LC-MS to the more commonly applied immunoassay approach for identifying artifact protein residues. That section is followed by our methods, results, and discussion.

\section{Immunoassay and LC-MS}

The most commonly applied approach in the realm of protein residue analysis is immunoassay (e.g., Kooyman et al. 2001; Lowenstein et al. 2006; Marlar et al. 2000), which has the advantage of finding "a needle in the haystack" of protein residues (such as blood on stone tools or food proteins in cooking pottery) within a matrix of exogenous sources (e.g., soil microbe proteins). Mass spectrometry approaches that provide a general scan of archaeological protein residues from cooking pottery, on the other hand, may not pinpoint original residues because exogenous proteins can overwhelm their signal (but see Cappellini et al. 2010; Heaton et al. 2009; Nielsen-Marsh 2005; Solazzo et al. 2008). Put simply, when using mass spectrometry, a morass of exogenous protein from soil bacteria can overwhelm the signals of more archaeologically meaningful residues leaving them undetected. This is not surprising given the observation of similar problems in ancient DNA research (e.g., Carpenter et al. 2013).

A strength of mass spectrometry, however, is that whatever peptides are identified are probabilistically matched to records of peptide sequences in large digital archives, which provides statistical precision for characterizing protein residues. Immunoassay approaches rely on antibody-antigen reactions, which if positive, signal the presence of a particular type of protein (e.g., human myoglobin). In analytical chemistry, a well-known problem with immunoassay is the issue of "non-specific binding" or "cross-reactivity" in which molecules other than the targeted protein react with the antibody, causing a false positive (Graves 1988; Waterboer et al. 2006), in addition to the general problems derived from protein deterioration (Fogel and Tuross 1999; van Doorn et al. 2012). Analytical chemists assess the probability of cross reactivity experimentally using analytes similar to the targeted protein, making sure there are not problems of nonspecific binding.

An important problem with the application of immunoassay in archaeological residue analysis is that protein structures can become modified through diagenesis over time in variable microenvironments (Grupe et al. 2000; van Doorn et al. 2012; Warinner et al. 2014). Thus, the extent of the problem of crossreactivity may be difficult to gauge. Due to the potential modification of proteins, immunoassay may produce false positive or false negative results. Archaeological chemists who study protein residues are left with an uncomfortable compromise; immunoassay residue techniques are targeted, sensitive, and 
thus likely to detect residues if they are present at trace levels, but require that the researcher accept uncertainty about the problem of cross-reactivity. Alternatively, the use of non-targeted mass spectrometry provides greater certainty concerning protein identification. However, this requires that the researcher compromise on the ability to detect trace amounts of archaeologically meaningful residues, as the entire suite of proteins/peptides in a given sample is analyzed at once, which increases background noise. One way to overcome this limitation is to advance technical development of protein mass spectrometry in archaeological chemistry as has already been accomplished for bone proteins (Buckley et al. 2009; Cappellini et al. 2014; van Doorn et al. 2011). The limitations of immunoassay and the potential of LC-MS (sensu Cappellini et al. 2014) warrant such method development and verification of our approach through identification of proteins from zooarchaeological specimens of known identity.

\section{Methods}

The bone specimens analyzed in this study are from sites in the Goodman Point Unit of Hovenweep National Monument in southwestern Colorado that were excavated by Crow Canyon Archaeological Center, Colorado, USA. A total of nine lagomorph ('L1' - 'L9'), nine turkey ('M1' - 'M9'), and four sciurid ('S1' - 'S4') specimens were selected from faunas recovered from four sites, Harlan Great Kiva (5MT16805), Thunder Knoll (5MT16778), Midway House (5MT16783), and Monsoon House (5MT16808), that span the Pueblo II (AD 950-1150) and Pueblo III (AD 1150-1350) time periods of the American Southwest (Table 1). Lagomorphs and turkeys were important components of prehistoric diet and are abundant in archaeological faunas; sciurid remains are less common (Badenhorst and Driver 2009; Muir and Driver 2002). All bone specimens were identified on the basis of diagnostic morphological characteristics and through comparison to reference materials housed in the University of North Texas Laboratory of Zooarchaeology following standards published by Driver (1992, 2011) and Wolverton (2013). All specimens exhibited good preservation (e.g., intact or semi-intact long bones with glossy surfaces, flexibility, and the absence of cracking or burn marks).

The protein residue extraction procedures used in this research were originally developed for the maximum quantitative recovery of protein residues from ceramic matrices (Barker et al. 2012). Their utility for bone protein extraction was preliminarily validated through previous attempts using individual samples of archaeological bone (see Barker 2011; Wolverton et al. 2014), but were here applied for the first time to a relatively large and diverse collection of specimens. Briefly, we pulverized a portion of each bone sample in a sterile mortar and pestle. Subsamples (250 - $500 \mathrm{mg}$ ) of this were placed in amber glass vials, and the protein solubilized in $2 \%$ sodium dodecyl sulfate (SDS) (w/v) in Milli-Q water (MQ) via exposure to high pressure and temperature $\left(108^{\circ} \mathrm{C}\right)$ in an autoclave for 60 minutes. Afterwards, solids were pelleted via centrifugation (14000g x 5 minutes). The supernatants were pipetted into new vials and centrifuged again to ensure the removal of all particulate matter. The final, clear, colorless to straw-colored solutions were concentrated and purified using Amicon $3 \mathrm{kD}$ centrifugal filters (Millipore part number UFC800324, Billerica, MA, USA), with a total of three, $3 \mathrm{~mL}$ MQ 'washes' to assist in the removal of non-protein contaminants (e.g., salts or bacterial metabolites). The concentration of SDS used, in combination with the complex composition of the extracted solution (which presumably included fatty acids, nucleic acids, and decomposition products such as humic acids), resulted in micelle formation and/or other unidentified impediments to hinder flowthrough rates. Though not problematic in terms of retaining proteins, as confirmed by experimental validation as well as discussion with the product manufacturer, this often resulted in centrifuge times longer than those recommended in the product guide. The final round of filtration was continued until the filtrate volume was between 200 and $500 \mu \mathrm{L}$, at which point the solution was gently agitated with a Pasteur pipette and then transferred into a fresh microcentrifuge vial.

Of this final filtrate, $30 \mu \mathrm{L}$ was further processed following the filter-aided sample preparation (FASP) protocol reported by Wiśniewski et al. (2009), while the remainder was set aside as a reference specimen for future analyses. FASP kits (Expedeon part number 44250, San Diego, CA, USA) were used to purify and concentrate recovered proteins/peptides following the manufacturer's protocol. After elution of protein digestate, samples were acidified with formic acid, desalted with C-18 zip tips (Millipore part number ZTC18S096, Billerica, MA, USA), and then evaluated using LC-MS. 
Table 1. Provenience and zooarchaeological information for rabbit (Lagomorpha: L), turkey (Meleagris gallopavo Linnaeus Phasianidae: M), and squirrel (Sciuridae: S) samples included in this study.

\begin{tabular}{|c|c|c|c|c|c|c|c|}
\hline Label & Element & Side & Site \# & Study Unit Type & Stratum & Level & Time Period (A.D.) \\
\hline L1 & Tibia & $\mathrm{R}$ & 5МT16805 & Masonry Structure & 1 & - & Approx. 1150 \\
\hline L2 & Femur & $\mathrm{R}$ & & Masonry Structure & $3^{*}$ & - & Approx. 1150 \\
\hline L3 & Tibia & $\mathrm{R}$ & & Masonry Structure & 4 & - & Approx. 1000 \\
\hline L4 & Tibia & L & & Masonry Structure & 4 & - & Approx. 1000 \\
\hline L5 & Humerus & $\mathrm{R}$ & 5МT16778 & Midden & 2 & 2 & $1060-1260$ \\
\hline L6 & Tibia & L & & Midden & 1 & 4 & $1060-1260$ \\
\hline L7 & Femur & $\mathrm{R}$ & & Midden & 1 & 3 & $1060-1260$ \\
\hline L8 & Tibia & $\mathrm{L}$ & 5МT16808 & Masonry Structure & 1 & - & $1150-1280$ \\
\hline L9 & Tibia & $\mathrm{R}$ & & Kiva & 2 & 2 & $1245-1260$ \\
\hline M1 & Coracoid & $\mathrm{R}$ & & Midden & 1 & 5 & $1060-1260$ \\
\hline M2 & Femur & $\mathrm{L}$ & & Midden & 2 & - & $1060-1260$ \\
\hline M3 & Humerus & $\mathrm{L}$ & & Kiva & 3 & - & $1140-1260$ \\
\hline M4 & Carpometacarpus & $\mathrm{R}$ & & Kiva & 3 & 2 & $1140-1260$ \\
\hline M5 & Tibia & $\mathrm{L}$ & & Masonry Structure & 1 & - & $1140-1260$ \\
\hline M6 & Femur & $\mathrm{R}$ & 5МT16778 & Pit Feature & 1 & - & $1140-1260$ \\
\hline M7 & Coracoid & L & & Midden & 1 & 2 & $1060-1260$ \\
\hline M8 & Humerus & $\mathrm{R}$ & & Midden & - & - & $1140-1260$ \\
\hline M9 & Carpometacarpus & $\mathrm{R}$ & & Midden & 2 & 2 & $1060-1260$ \\
\hline S1 & Mandible & $\mathrm{R}$ & 5МT16783 & Midden & 2 & 2 & $1060-1260$ \\
\hline S2 & Humerus & $\mathrm{R}$ & & Midden & 2 & 4 & $1060-1260$ \\
\hline S3 & Humerus & L & & Midden & 2 & 3 & $1060-1260$ \\
\hline S4 & Humerus & $\mathrm{L}$ & 5МT16805 & Great Kiva & - & - & $1140-1240$ \\
\hline
\end{tabular}

${ }^{*}$ Some burrowing disturbance is evident.

Method blanks (to which no bone material was added) were processed alongside archaeological samples to evaluate contamination. Given that samples were collected in the field and sorted by hand prior to receipt at the research facilities, we anticipated the presence of common contaminants such as keratins. Further, the size, thickness and intactness (some were cracked open) of our specimens prevented the confident removal of exterior contamination via grinding or other means. However, we minimized any additional contamination by wearing latex or nitrile gloves during all lab procedures, by carefully preparing all reagents and equipment (e.g., washing glassware prior to use, heat-sterilizing mortars and pestles), and by performing all extraction and sample preparation procedures in a dedicated workspace at the University of North Texas.

LC-MS/MS analysis was conducted at the University of South Florida using previously-reported protocols (see Barker et al. 2012). Raw data files were processed by extract_msn.exe through the Mascot Daemon (v.2.2.2) program. Protein identifications were performed via the MASCOT search engine (Matrix Science, London, UK; v2.2.06) in which the extracted mass spectrometric data were searched against the SwissProt database (v2013_07, 1068484 entries), with fragment ion mass tolerance of $0.80 \mathrm{Da}$, parent mass tolerance of $2.5 \mathrm{Da}$, trypsin as the digestion enzyme, and a maximum of 1 missed cleavage. Carbamidomethylation was specified as a fixed modification. Oxidation of proline and methionine, and deamidation of asparagine and glutamine were specified as variable modifications. Peptide and protein identification probability values were generated via the Peptide and Protein Prophet algorithms (Keller et al. 2002, Nesvizhskii et al. 2003). Identifications were accepted for peptides if false detection rates (FDR) were less than $1.0 \%$. For proteins, 
positive matches required a minimum of 3 identified peptides to acheive FDR values of less than 1.0\%. Further, our criteria for protein identification mirror those presented in Cappellini et al. (2012) and in our previous research (Stevens et al. 2010) in that, in addition to the above criteria, we consider 2 or more exclusive unique peptides (those that are sourced only to a given protein) as a positive indicator for the presence of a given protein (but see 'Results' below). Raw data files as well as processed Scaffold files have been submitted to the ProteomeXchange Consortium (http://proteomecentral.proteomexchange.org) via the PRIDE partner repository (Vizcaino et al., 2013) with the dataset identifier PXD002440 and 10.6019/ PXD002440, respectively.

\section{Results}

In addition to common, and reasonably-expected, contaminants (e.g., human keratins) we identified a variety of unique proteins in archaeological samples and not method blanks (Table 2). Collagen alpha-1(I) chains were identified in all tested archaeological samples. Matches to other collagen isoforms, most commonly collagen alpha-2(I), were also observed. The consistent recovery of collagens is not an unexpected result considering their hydrophobicity, which promotes preservation, as well as collagens' documented resistance to several sources of degradation (see Child 1995; Collins et al. 2002; Dobberstein et al. 2009), and the number of previous studies that have successfully identified ancient bone collagens (e.g., Buckley et al. 2014; van Doorn et al. 2011; Welker et al. 2015).

Some of the lagomorph samples also yielded noncollagen proteins (Table 2). Aside from keratins, which are possibly contaminants derived from handling during sample collection or processing, these include elongation factors $\mathrm{Tu}$ and $\mathrm{G}$, synapsin-1, eosinophil peroxidase, and tubulin alpha-1B. Elongation factor $\mathrm{Tu}$, which does not meet our most stringent criteria for positive identification (only 1 exclusive unique peptide was identified), is sourced to Burkholderia spp. These gram-negative bacteria are well -known mammalian pathogens that most commonly infect Equus spp., but have been documented to infect humans, rabbits, and other mammals. Though endemic in Africa and Asia, they are considered eradicated in North America (Fritz et al. 2000; Whitlock et al. 2007). Assuming that this match is legitimate, it may be evidence of ancient disease. Elongation factor G, sourced to Agrobacterium radiobacter, is likely the result of contamination from soil; A. radiobacter is a common soil bacterium that has been used for agricultural purposes throughout the world (Moore and Warren 1975). We rule out synapsin-1 due to the poor quality spectra (limited sequence coverage and low signal-to-noise ratios) that were obtained (see ProteomeXchange supplementary material). Eosinophil peroxidase and tubulin alpha-1B both occur in mammalian tissues. Thus, our observed matches to these proteins may reflect their survival in ancient lagomorph remains (but see below).

More surprisingly, though not unprecedented given the reports of a variety of blood and muscular proteins in zooarchaeological/paleontological bones (see Ascenzi et al. 1985; Cappellini et al. 2012; Smith \& Wilson 1990; Tuross 1991), we identified hemoglobin and ferritin proteins after relaxation of our match criteria (from 3 to 1 exclusive unique peptide while still maintaining a $1 \%$ peptide FDR and adjusting the protein identification probability to $95 \%$ ). This filtering revealed additional blood-derived proteins in samples L1, L2 and L3 (Table 3), as well as other protein matches of variable quality (not reported here, but see ProteomeXchange supplementary file). In particular, we identified hemoglobin beta, sourced to European hare (Lepus europaeus Pallas Leporidae) in all three samples, and ferretin (light chain) sourced to European rabbit (Oryctolagus cuniculus Linnaeus Leporidae) in L1 and L2 (Figure 1a, b). The annotated MS/MS spectra clearly show high-quality matches based on visual inspection. Additionally, while protein sequences for hemoglobin beta are available in the Uniprot database for several organisms, including human, no sequence identity was observed for the identified tryptic peptides. This result indicates a higher probability match to L. europaeus. Moreover, the ferretin (light chain) match seems to be specific to $O$. cuniculus based on the "Similarity View" in the Scaffold file. That both identified proteins are sourced to lagomorphs and that both are found in blood suggests the presence of preserved lagomorph blood residues in these samples.

Results also demonstrate modification of proteins/peptides. In particular, we observed oxidation of proline and methionine as well as deamidation of glutamine and asparagine (Figure 2A). Many such modifications occur endogenously (as posttranslational modifications). For example, enzymatic hydroxylation of proline residues in collagen is a key step in the stabilization of the collagen triple helix 
Table 2. Identified proteins for Lagomorpha (L), Meleagris gallopavo (M) and Sciuridae (S) samples. Numbers represent the count of exclusive unique peptides identified, with a value of 2 or greater indicating a positive match. For ease of viewing, closely homologous proteins are grouped as 'clusters.' Thus, a match to a given cluster does not necessarily reflect the correct taxonomic assignment as listed here. The number in parentheses after the accession number reflects the total number of taxa included in that cluster. See the Scaffold file (Similarity View) that is available in the online supplementary material through ProteomeXchange for an expanded list of assignments.

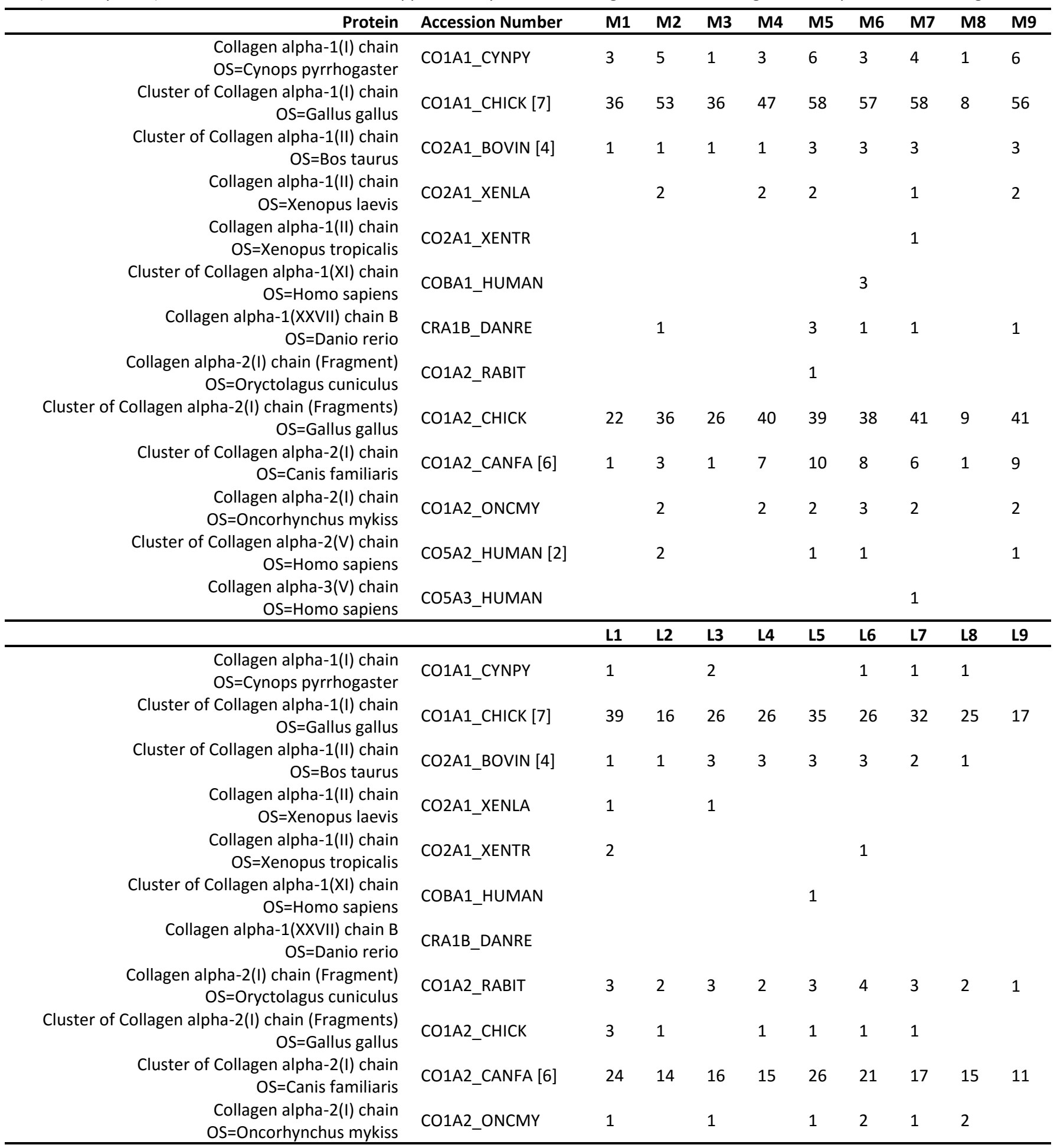

(continued on next page) 


\begin{tabular}{|c|c|c|c|c|c|c|c|c|c|c|}
\hline Protein & Accession Number & L1 & $\mathrm{L2}$ & L3 & L4 & $\mathbf{L 5}$ & $\mathrm{L6}$ & $\mathbf{L 7}$ & $\mathrm{L8}$ & $\mathrm{Lg}$ \\
\hline $\begin{array}{r}\text { Cluster of Collagen alpha-2(V) chain } \\
\text { OS=Homo sapiens }\end{array}$ & CO5A2_HUMAN [2] & 3 & 2 & & & 1 & 2 & 1 & 4 & \\
\hline $\begin{array}{r}\text { Collagen alpha-3(V) chain } \\
\text { OS=Homo sapiens }\end{array}$ & CO5A3_HUMAN & & & & 1 & & & & 3 & \\
\hline $\begin{array}{l}\text { Cluster of Elongation factor } \mathrm{G} \\
\text { OS=Agrobacterium radiobacter }\end{array}$ & EFG_AGRRK & 1 & & 3 & & & & & & \\
\hline $\begin{array}{r}\text { Elongation factor Tu } \\
\text { OS=Burkholderia mallei }\end{array}$ & EFTU_BURM7 (+8) & & & 1 & & & & 1 & & \\
\hline $\begin{array}{r}\text { Eosinophil peroxidase } \\
\text { OS=Homo sapiens }\end{array}$ & PERE_HUMAN & 1 & 4 & 1 & & & & & & \\
\hline $\begin{array}{r}\text { Cluster of Keratin, type I cytoskeletal } 10 \\
\text { OS=Homo sapiens }\end{array}$ & K1C10_HUMAN & 1 & 2 & 3 & 2 & 2 & & 4 & & \\
\hline $\begin{array}{r}\text { Keratin, type I cytoskeletal } 9 \\
\text { OS=Homo sapiens }\end{array}$ & K1C9_HUMAN & 5 & 1 & 1 & 3 & 1 & 2 & 4 & & \\
\hline \multirow{4}{*}{$\begin{array}{r}\text { Cluster of Keratin, type II cytoskeletal } 2 \text { epidermal } \\
\text { OS=Homo sapiens } \\
\text { Cluster of Synapsin-1 (Fragment) } \\
\text { OS=Canis familiaris } \\
\text { Tubulin alpha-1B chain } \\
\text { OS=Bos taurus }\end{array}$} & K22E_HUMAN [3] & 3 & 1 & 1 & 2 & 2 & 1 & 5 & 2 & \\
\hline & SYN1_CANFA & 2 & & & & & & & 3 & \\
\hline & TBA1B_BOVIN (+22) & 1 & 3 & & & & & & & \\
\hline & & S1 & S2 & S3 & S4 & & & & & \\
\hline \multirow{5}{*}{$\begin{array}{r}\text { Collagen alpha-1(I) chain } \\
\text { OS=Cynops pyrrhogaster } \\
\text { OS=Gallus gallus } \\
\text { Cluster of Collagen alpha-1(I) chain } \\
\text { Cluster of Collagen alpha-1(II) chain } \\
\text { OS=Bos taurus } \\
\text { Collagen alpha-2(I) chain (Fragment) } \\
\text { OS=Oryctolagus cuniculus } \\
\text { Cluster of Collagen alpha-2(I) chain (Fragments) }\end{array}$} & CO1A1_CYNPY & & & & & & & & & \\
\hline & CO1A1_CHICK [7] & 4 & 2 & 7 & 4 & & & & & \\
\hline & CO2A1_BOVIN [4] & 1 & & 1 & & & & & & \\
\hline & CO1A2_RABIT & & & & & & & & & \\
\hline & CO1A2_CHICK & 1 & & & & & & & & \\
\hline $\begin{array}{r}\text { Cluster of Collagen alpha-2(I) chain } \\
\text { OS=Canis familiaris }\end{array}$ & CO1A2_CANFA [6] & 4 & & 3 & 1 & & & & & \\
\hline
\end{tabular}

(and is therefore accounted for by search engines). However, other modifications maybe derived from natural diagenetic processes or even from laboratory procedures (Grupe et al. 2000; Mikšik et al. 2014; Van Doorn et al. 2012), and are therefore less predictable. As an example, a collagen-derived tryptic peptide from the sequence shown in Figure 2A was identified with either an oxidized or non-oxidized methionine. The corresponding MS/MS spectra show the confident identification of both peptide species (Figure $2 \mathrm{~B}$ and $\mathrm{C}$ ). On one hand, the identification of anticipated diagenetic modifications in archaeological samples may provide support to the interpretation of identified proteins as being authentic. Welker et al. (2015), for example, use glutamine deamidation ratios to support the interpretation of their identified residues as being legitimately ancient. On the other hand, variability in modifications, as influenced by differential microenvironments (see van Doorn et al. 2012), makes successful identification more difficult; each unique modification results in a peptide/ion of a different molecular weight than the original, meaning that a collection of originally identical peptides will feature variable mass spectra once differentially modified. Error tolerant search algorithms account for this issue, but require increased processing time/ power and may increase uncertainty of identification. To date, the potential problems arising from such modifications have not been fully addressed in regards to archaeological residues (but see Cappellini et al. 2012; van Doorn et al. 2011), but the ability to account for such modifications is an inherent strength of mass spectrometry-based approaches.

In our non-targeted method, homology is clearly a potential problem. For lagomorph samples, collagen alpha-2(I) (fragment) was correctly identified as 
Table 3. When search criteria are relaxed, two blood-derived proteins are observed in three lagomorph samples. Numbers represent the count of exclusive unique peptides.

\begin{tabular}{rllll}
\hline & Accession & & \\
Protein & Number & L1 & L2 & L3 \\
\hline $\begin{array}{r}\text { Hemoglobin subunit beta } \\
\text { OS=Lepus europaeus }\end{array}$ & HBB_LEPEU & 2 & 2 & 1 \\
$\begin{array}{r}\text { Ferritin light chain } \\
\text { OS=Oryctolagus cuniculus }\end{array}$ & FRIL_RABIT & \multicolumn{2}{c}{2} & \\
\hline
\end{tabular}

originating from a lagomorph source (O. cuniculus) in 8 of 9 samples (with the last, 'L9' only containing one of the requisite exclusive unique peptides instead of two). For other samples, however, taxonomic specificity was less clear, with turkey, rabbit and squirrel collagens variously assigned to more than one potential taxonomic origins. Nevertheless, strength of matches generally correlates with the degree to which a given match is taxonomically correct. For example, though the collagen alpha-1(I) recovered from the turkey samples contained some peptides that could be sourced to mouse (Mus musculus Linnaeus Muridae), the highest numbers of exclusive unique peptides from these samples were sourced to junglefowl (Gallus gallus Linnaeus Phasianidae), the most closely related taxon in the database that we searched.

Homology (but also the lack of taxonomically specific reference sequences) posed similar challenges in the identification of some of the non-collagen proteins recovered from lagomorph samples. Eosinophil peroxidase, recovered from sample L2 (also in L1 and L3 if criteria are relaxed), is represented by four exclusive unique peptides. The assignment of these to a human, rather than lagomorph, source is based on a single amino acid substitution (LàI) in one of the four recovered peptides (R.NQINALTSFVDASMVYGSEVSLSLR.L). However, because the lagomorph
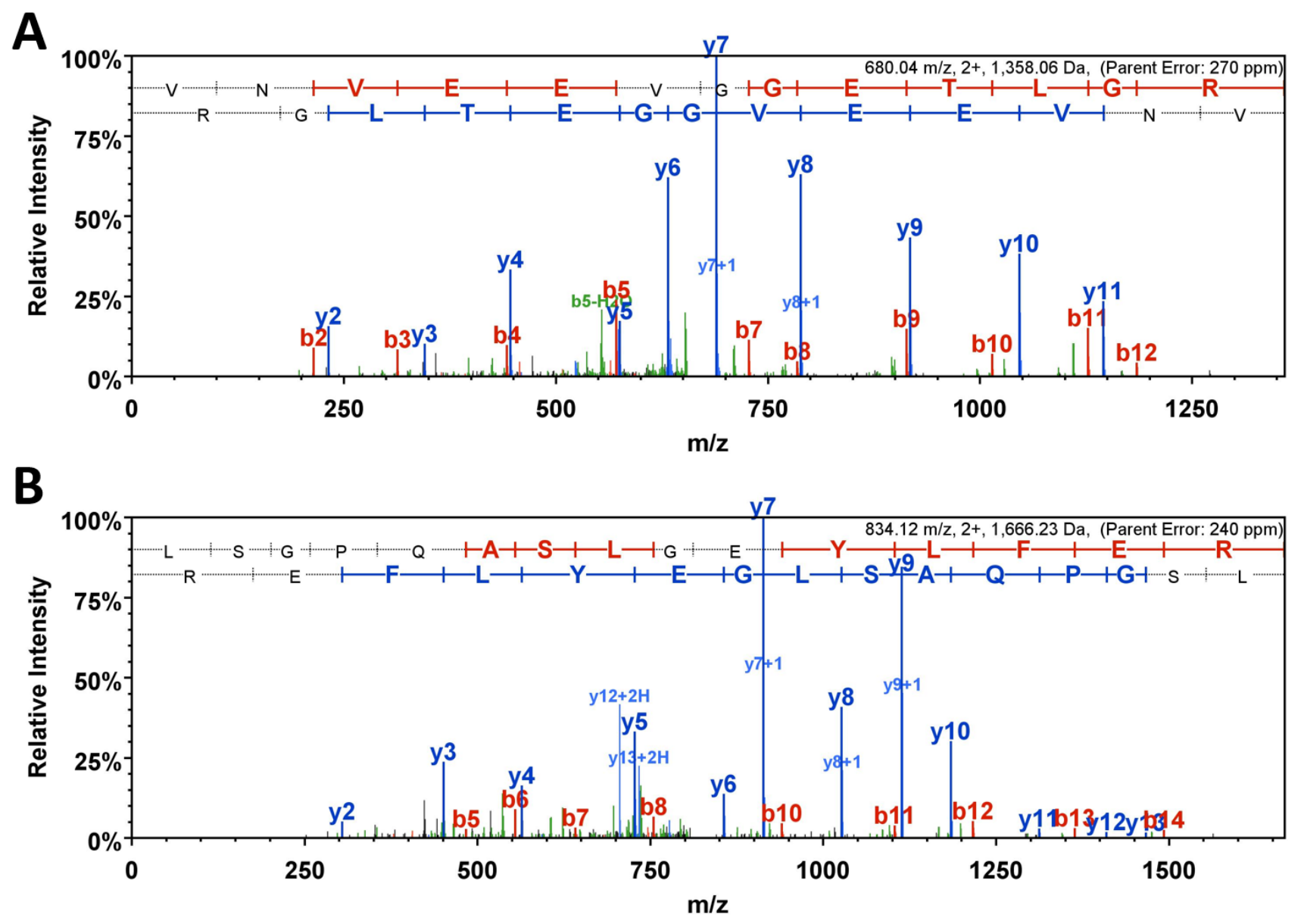

Figure 1. Representative MS/MS spectra for tryptic peptides of (A) hemoglobin subunit beta (Lepus europaeus Pallas Leporidae) and (B) and ferritin light chain (Oryctolagus cuniculus Linnaeus Leporidae) found in our lagomorph bone specimens. 
A

C01A1_CHICK (100\%), 137,754.3 Da

Collagen alpha- $1(\mathrm{I})$ chain $\mathrm{OS}=\mathrm{Gallus}$ gallus $\mathrm{GN}=\mathrm{COL} 1 \mathrm{~A} 1 \mathrm{PE}=1 \mathrm{SV}=3$

25 exclusive unique peptides, 44 exclusive unique spectra, 1203 total spectra, $679 / 1453$ amino acids (47\% coverage)

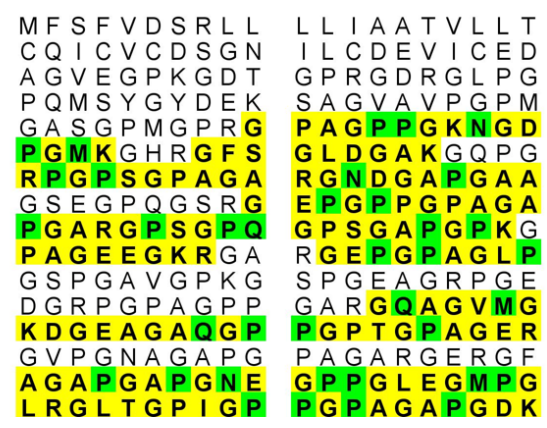

RGEGEED I Q T TSDCPNAE IP $P P G R D G I P G Q$ GPAGPRGLPG DGEAGKPGRP $P A G P K G E P G S$ G P P G P T G P A G A G P A G N P G A D N S GE P GAPGN GPAGERGAPG GPAGERGAPG
A GLPGAKGLT FPGPKGAAGE GEQGPAGAPG P G E R V VOG P P ERGA A GLPGA
GE A GP P P A G
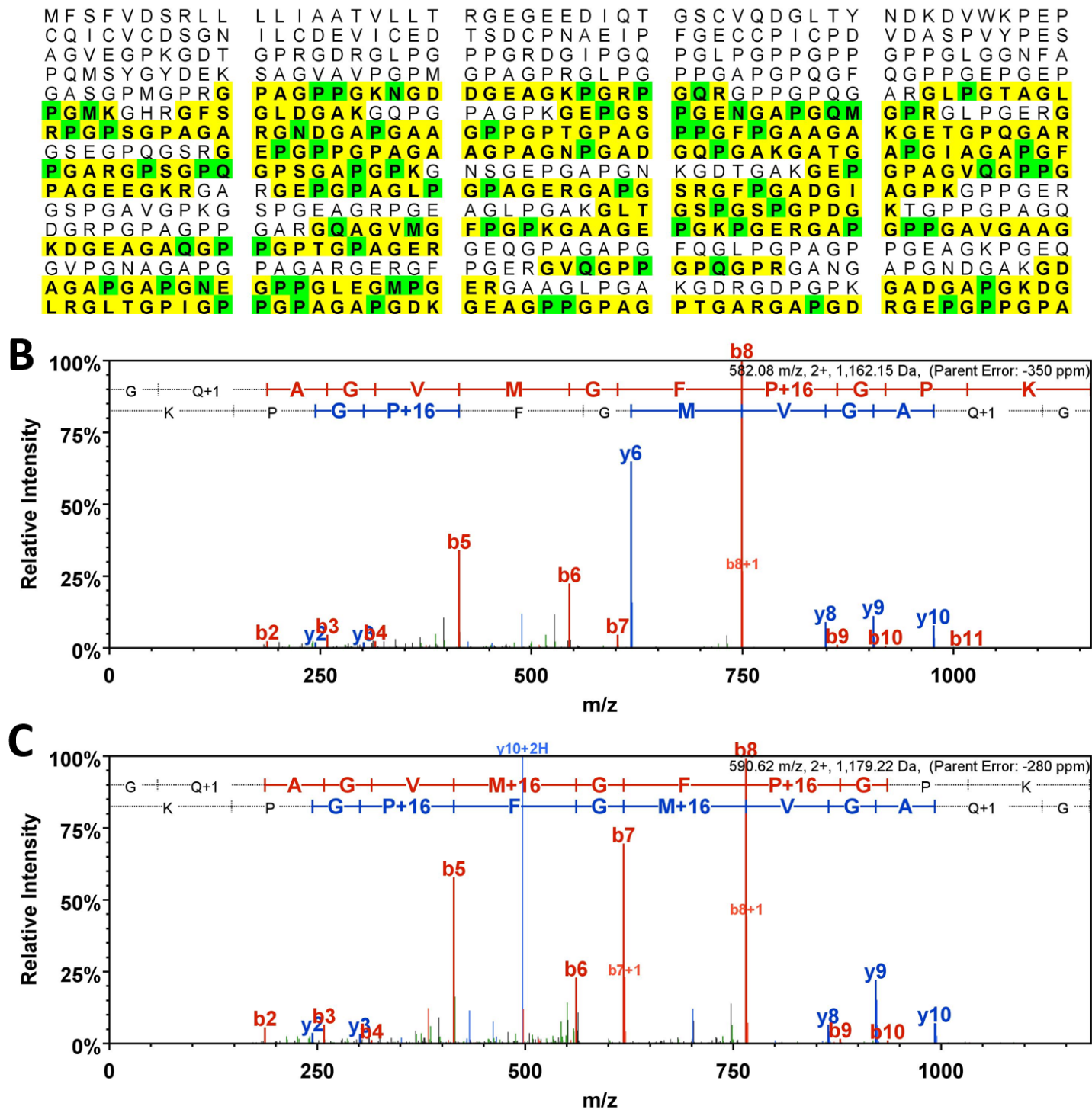

Figure 2. (A) Sequence coverage (highlighted) of junglefowl (Gallus gallus Linnaeus Phasianidae) collagen alpha-1(I) chain by sample M6. Green highlighted amino acids have been chemically modified (Oxidation - M, P) (Deamidation - N, Q). Though proline hydroxylation occurs endogenously as part of post translational modification, the extensive modification of other amino acids supports the interpretation of the recovered residue as being ancient. (B and C) Annotated MS/MS spectra showing a tryptic peptide derived from G. gallus collagen alpha-1(I) chain containing either B) a non-oxidized or C) oxidized methionine residue. The diagnostic peak representing neutral loss of methane sulfenic acid ( $64 \mathrm{Da}$ or $\mathrm{m} / \mathrm{z} 32$ for a +2 ion) increases confidence of identification for the oxidized methionine-containing peptide in C). Interestingly, part of the bion series is isobaric with the $y$-ion series but only labeled as the corresponding $b$-ion even though fragment ion tolerance was $\pm 0.8 \mathrm{Da}$. For example, the b7 ion in the oxidized form in C) is isobaric with the y6 ion but is only annotated as b7 by Scaffold. The low mass accuracy and resolution of the linear ion trap in not able to distinguish between the $b$ - or $y$ - ions; however, it would be expected, given the absence of internal basic residues at the $\mathrm{N}$-terminal portion of the sequence, that the $y$ ions would be the predominant signal. 
reference sequence is derived from O. cuniculus rather than a North American species, we cannot be certain that this assignment is correct. Similarly, tubulin alpha $-1 \mathrm{~B}$ is highly conserved across species, as reflected by the large cluster size (see Table 2), making it difficult to assign to specific taxonomic origin.

The challenges of homology are well-known in this type of research, have previously been addressed by others (see Buckley et al. 2009; 2010, 2014; van Doorn et al. 2011), and are irrelevant to the proximate goals of our research; our successful identifications demonstrate that our experimentally-optimized method is applicable to archaeological proteins, that (some) proteins readily preserve under the contexts of our target study area (southwestern Colorado) and that non-targeted methods can still be useful so long as issues of homology are considered.

\section{Summary and Conclusion}

We extracted and characterized proteins from zooarchaeological bone of known identity in order to verify an ability to classify ancient proteins using our non-targeted LC-MS approach. This approach had mainly been applied to artifact residues from tightly controlled cooking experiments (Barker et al. 2012; Stevens et al. 2010) or as identification of bone proteins from individual specimens (Barker 2011; Wolverton et al. 2014). Our results indicate that our approach, which includes optimized extraction and solvent parameters from previous research (Barker et al. 2012), leads to reliable identification of proteins when they are extracted from ancient bone. For example, we have been able to characterize multiple types of protein, including hemoglobin, and collagens (see also Buckley and Wadsworth 2014). Taxonomic identifications vary according to the homology of the protein (how conserved it is across various biological taxa) and peptide sequences commonly recorded in databases (e.g., North American lagomorphs are identified as European hares and rabbits). Our results add little to the growing literature on identification of collagen from bone via ZooMS; however, the merit of our results relates to the trajectory of method development in archaeological protein residue research in which this verification study is contextualized.

The next phase of our research is to use the nontargeted approach employed in this study to analyze food and protein-mixture residues from pottery used in cooking experiments. In rare cases of exceptional residue abundance and preservation we expect that this non-targeted approach will aid in characterizing past dietary remains from cooking pottery. In most cases, however, we anticipate that dietary protein residues will occur in trace quantities due to the taphonomic processes (e.g., diagenesis) that occur when proteins are removed from their tissues of origin. Another step forward will be to characterize commonly occurring protein residues from cooking experiments using the non-targeted approach employed here. This suite of commonly encountered proteins will be used to develop targeted LC-MS methods that are more sensitive and thus more likely to detect residues in trace quantities. The results presented here represent an important milestone, in that we can move forward along this research trajectory aware that this approach works well for identifying multiple types of ancient protein from bone. This process of method development has important implications for archaeological ethics; our research moves beyond the common archaeological practice of simply applying approaches from contemporary analytical chemistry to artifacts in hope of encountering preserved biomolecular residues. We do this through substantial efforts toward optimization and validation. Such method development is expected in analytical chemistry and can only improve the potential for archaeological chemistry in the longterm.

\section{Acknowledgments}

Four anonymous reviewers provided detailed comments on a previous submission of this paper that helped us improve its focus and content.

\section{Declarations}

Permissions: We thank Crow Canyon Archaeological Center for aiding us in this research project and the National Park Service, particularly Hovenweep National Monument, for access to remains analyzed in this study.

Sources of Funding: This study was partially funded by NSF Archaeometry Technical Development Grant No. 1112615.

Conflicts of Interest: Co-author Steve Wolverton is a former editor of Ethnobiology Letters and currently serves as a member of its editorial board.

\section{References Cited}

Ascenzi, A., M. Brunori, G. Citro and R. Zito. 1985. Immunological Detection of Hemoglobin in Bones of Ancient Roman Times and of Iron and Eneolith- 
ic Ages. Proceedings of the National Academy of Sciences 82:7170-7172.

Badenhorst, S. and J. C. Driver. 2009. Faunal Changes in Farming Communities from Basketmaker II to Pueblo III (AD 1-1300) in the San Juan Basin of the American Southwest. Journal of Archaeological Science 36:1832-1841. Doi:10.1016/

j.jas.2009.04.006.

Barker, A. 2011. Archaeological Protein Residues: New Data for Conservation Science. Ethnobiology Letters 1:58-65.

Barker, A., B. Venables, S. M. Stevens, Jr., K. W. Seeley, P. Wang and S. Wolverton. 2012. An Optimized Approach for Protein Residue Extraction and identification from Ceramics after Cooking. Journal of Archaeological Method and Theory 19:407-439.

Barnard, H., L. Shoemaker, O. E. Craig, M. Rider, R. E. Parr, M. Q. Sutton and R. M. Yohe II. 2007. Introduction to the Analysis of Protein Residues in Archaeological Ceramics. In Theory and Practice of Archaeological Residue Analysis, edited by $\mathrm{H}$.

Barnard, and J. W. Eerkens, pp. 216-228 Archaeopress, Oxford.

Buckley, M., M. Collins, J. Thomas-Oates and J. C. Wilson. 2009. Species Identification by Analysis of Bone Collagen Using Matrix-Assisted Laser Desorption/Ionisation Time-of-Flight Mass Spectrometry. Rapid Communications in Mass Spectrometry 23:3843-3854. Doi:10.1002/rcm.4316.

Buckley, M., S. Fraser, J. Herman, N. D. Melton, J. Mulville and A. H. Pálsdóttir. 2014. Species Identification of Archaeological Marine Mammals Using Collagen Fingerprinting. Journal of Archaeological Science 41:631-641. Doi:http:// dx.doi.org/10.1016/j.jas.2013.08.021.

Buckley, M., S. W. Kansa, S. Howard, S. Campbell, J. Thomas-Oates and M. Collins. 2010. Distinguishing between Archaeological Sheep and Goat Bones Using a Single Collagen Peptide. Journal of Archaeological Science 37:13-20.

Buckley, M. and C. Wadsworth. 2014. Protein Degradation in Ancient Bone: Diagenesis and Phylogenetic Potential. Paleogeography, Palaeoclimatology, Palaeoecology 416:69-79.
Cappellini, E., M. J. Collins and M. T. P. Gilbert. 2014. Unlocking Ancient Protein Palimpsests. Science 343:1320-1322. Doi:10.1126/ science.1249274.

Cappellini, E., M. T. P. Gilbert, F. Geuna, G. Fiorentino, A. Hall, J. Thomas-Oates, P. D. Ashton, D. A. Ashford, P. Arthur, P. F. Campos, J. Kool, E. Willerslev and M. J. Collins. 2010. A Multidisciplinary Study of Archaeological Grape Seeds. Naturwissenschaften 97:205-217. Doi:10.1007/s00114009-0629-3.

Cappellini, E., L. J. Jensen, D. Szklarczyk, A. Ginolhac, R. A. R. da Fonseca, T. W. Stafford, S. R. Holen, M. J. Collins, L. Orlando, E. Willerslev, M. T. P. Gilbert and J. V. Olsen. 2012. Proteomic Analysis of a Pleistocene Mammoth Femur Reveals More Than One Hundred Ancient Bone Proteins. Journal of Proteome Research 11:917-926.

Carpenter, Meredith L., Jason D. Buenrostro, C. Valdiosera, H. Schroeder, Morten E. Allentoft, M. Sikora, M. Rasmussen, S. Gravel, S. Guillén, G. Nekhrizov, K. Leshtakov, D. Dimitrova, N. Theodossiev, D. Pettener, D. Luiselli, K. Sandoval, A. Moreno-Estrada, Y. Li, J. Wang, M. Thomas P. Gilbert, E. Willerslev, William J. Greenleaf and Carlos D. Bustamante. 2013. Pulling out the 1\%: Whole-Genome Capture for the Targeted Enrichment of Ancient DNA Sequencing Libraries. The American Journal of Human Genetics 93:852-864. Doi:http://dx.doi.org/10.1016/j.ajhg.2013.10.002.

Child, A. M. 1995. Towards and Understanding of the Microbial Decomposition of Archaeological Bone in the Burial Environment. Journal of Archaeological Science 22:165-174. Doi:http://dx.doi.org/10.1006/ jasc.1995.0018.

Collins, M. J., C. M. Nielsen-Marsh, J. Hiller, C. I. Smith, J. P. Roberts, R. V. Prigodich, T. J. Wess, J. Csapo, A. R. Millard and G. Turner-Walker. 2002. The Survival of Organic Matter in Bone: A Review. Archaeometry 44:383-394.

Dobberstein, R. C., M. J. Collins, O. E. Craig, G. Taylor, K. E. H. Penkman and S. Ritz-Timme. 2009. Archaeological Collagen: Why Worry About Collagen Diagenesis? Archaeological and Anthropological Sciences 1:31-42. Doi:10.1007/s12520-0090002-7. 
Driver, J. C. 1992. Crow Canyon Archaeological Center Manual for Description of Vertebrate Remains. Crow Canyon Archaeological Center, Cortez, CO.

Driver, J. C. 2011. Identification, Classification and Zooarchaeology (Featured Reprint and Invited Comments). Ethnobiology Letters 1:19-39.

Fogel, M. L. and N. Tuross. 1999. Transformation of Plant Biochemicals to Geological Macromolecules During Early Diagenesis. Oecologia 120:336-346. Doi:10.1007/s004420050867.

Fritz, D. L., P. Vogel, D. R. Brown, D. Deshazer and D. M. Waag. 2000. Mouse Model of Sublethal and Lethal Intraperitoneal Glanders (Burkholderia mallei). Veterinary Pathology 37:626-636. Doi: 10.1354/vp.37-6-626.

Graves, H. C. B. 1988. The Effect of Surface Charge on Non-Specific Binding of Rabbit Immunoglobulin $\mathrm{G}$ in Solid-Phase Immunoassays. Journal of Immunological Methods 111:157-166. Doi:http:// dx.doi.org/10.1016/0022-1759(88)90123-8.

Grupe, G., A. Balzer and S. Turban-Just. 2000. Modeling Protein Diagenesis in Ancient Bone: Towards a Validation of Stable Isotope Data. In Biogeochemical Approaches to Paleodietary Analysis edited by S. H. Ambrose and M. A. Katzenburg, pp. 173-187. Kluwer Academic, New York.

Heaton, K., C. Solazzo, M. J. Collins, J. ThomasOates and E. T. Bergström. 2009. Towards the Application of Desorption Electrospray Ionisation Mass Spectrometry (Desi-Ms) to the Analysis of Ancient Proteins from Artefacts. Journal of Archaeological Science 36:2145-2154. Doi:http:// dx.doi.org/10.1016/j.jas.2009.05.016.

Keller, A., A. I. Nesvizhskii, E. Kolker and R. Aebersold. 2002. Empirical Statistical Model to Estimate the Accuracy of Peptide Identifications Made by Ms/Ms and Database Search. Analytical Chemistry 74:5383-5392. Doi:10.1021/ac025747h.

Kooyman, B., M. E. Newman, C. Cluney, M. Lobb, S. Tolman, P. McNeil and L.V. Hills. 2001. Identification of Horse Exploitation by Clovis Hunters Based on Protein Analysis. American Antiquity 66:686691.
Lowenstein, J. M., J. D. Reuther, D. G. Hood, G. Scheuenstuhl, S. C. Gerlach and D. H. Ubelaker. 2006. Identification of Animal Species by Protein Radioimmunoassay of Bone Fragments and Bloodstained Stone Tools. Forensic Science International 159:182-188.

Marlar, R. A., B. L. Banks, B. R. Billman, P. Lambert and J. E. Marlar. 2000. Biochemical Evidence of Cannibalism in a Prehistoric Pueblo Site in Southwestern Colorado. Nature 407:73-8.

Doi:10.1038/35024064

Mikšík, I., P. Sedláková, S. Pataridis, F. Bortolotti, R. Gottardo and F. Tagliaro. 2014. Prince Cangrande's Collagen: Study of Protein Modification on the Mummy of the Lord of Verona, Italy (1291-1329 Ad). Chromatographia 77:1503-1510. Doi:10.1007/ s10337-014-2710-0.

Moore, L. W. and G. Warren. 1979. Agrobacterium radiobacter Strain 84 and Biological Control of Crown Gall. Annual Review of Phytopathology 17:163-179.

Muir, R. J. and J. C. Driver. 2002. Scale of Analysis and Zooarchaeological Interpretation: Pueblo III Faunal Variation in the Northern San Juan Region. Journal of Anthropological Archaeology 21:165-199. Doi:10.1006/jaar.2001.0392.

Nesvizhskii, A. I., A. Keller, E. Kolker and R. Aebersold. 2003. A Statistical Model for Identifying Proteins by Tandem Mass Spectrometry. Analytical Chemistry 75:4646-4658. Doi:10.1021/ac0341261.

Nielsen-Marsh, C. M., M. P. Richards, P. V. Hauschka, J. E. Thomas-Oates, E. Trinkaus, P. B. Pettitt, I. Karavanić, H. Poinar and M. J. Collins. 2005. Osteocalcin Protein Sequences of Neanderthals and Modern Primates. Proceedings of the National Academy of Sciences of the United States of America 102:4409-4413. Doi:10.1073/ pnas.0500450102.

San Antonio, J. D., M. H. Schweitzer, S. T. Jensen, R. Kalluri, M. Buckley and J. P. R. O. Orgel. 2011. Dinosaur Peptides Suggest Mechanisms of Protein Survival. PLoS ONE 6:e20381. Doi:10.1371/ journal.pone.0020381.

Smith, P. R. and M. T. Wilson. 1990. Detection of Haemoglobin in Human Skeletal Remains by Elisa. Journal of Archaeological Science 17:255-268. 
Doi:http://dx.doi.org/10.1016/0305-4403(90) 90023-X.

Solazzo, C., W. W. Fitzhugh, C. Rolando and C. Tokarski. 2008. Identification of Protein Remains in Archaeological Potsherds by Proteomics. Analytical Chemistry 80:4590-4597. Doi:10.1021/ac800515v.

Stevens, S. M., Jr., S. Wolverton, B. Venables, A. Barker, K. W. Seeley and P. Adhikari. 2010. Evaluation of Microwave-Assisted Enzymatic Digestion and Tandem Mass Spectrometry for the Identification of Protein Residues from an Inorganic Solid Matrix: Implications in Archaeological Research. Analytical and Bioanalytical Chemistry 396:1491-1499. Doi:10.1007/s00216-009-3341-4.

Tuross, N. 1991. Recovery of Bone and Serum Proteins from Human Skeletal Tissue: Igg, Osteonectin, and Albumin. In Human Paleopathology: Current Syntheses and Future Options, edited by D. J. Ortner, and A. C. Aufderheide, pp. 51-54 Smithsonian Institution Press, Washington D.C.

van Doorn, N., H. Hollund and M. Collins. 2011. A Novel and Non-Destructive Approach for Zooms Analysis: Ammonium Bicarbonate Buffer Extraction. Archaeological and Anthropological Sciences 3:281-289. Doi:10.1007/s12520-011-0067-y.

van Doorn, N. L., J. Wilson, H. Hollund, M. Soressi and M. J. Collins. 2012. Site-Specific Deamidation of Glutamine: A New Marker of Bone Collagen Deterioration. Rapid Communications in Mass Spectrometry 26:2319-2327. Doi:10.1002/rcm.6351.

Vizcaino, J. A., Cote, R. G., Csordas, A., Dianes, J. A., Fabregat, A., Foster, J. M., et al. (2013). The PRoteomics IDEntifications (PRIDE) database and associated tools: status in 2013. [Research Support, Non-U.S. Gov't]. Nucleic acids research, 41 (Database issue), D1063-1069.

Warinner, C., J. F. M. Rodrigues, R. Vyas, C. Trachsel, N. Shved, J. Grossmann, A. Radini, Y. Hancock, R. Y. Tito, S. Fiddyment, C. Speller, J. Hendy, S. Charlton, H. U. Luder, D. C. Salazar-Garcia, E. Eppler, R. Seiler, L. H. Hansen, J. A. S. Castruita, S. Barkow-Oesterreicher, K. Y. Teoh, C. D. Kelstrup, J. V. Olsen, P. Nanni, T. Kawai, E. Willerslev, C. von Mering, C. M. Lewis Jr, M. J. Collins, M. T. P. Gilbert, F. Ruhli and E. Cappellini. 2014. Pathogens and Host Immunity in the Ancient Human Oral Cavity. Nat Genet 46:336-344. Doi:10.1038/ng.2906
Waterboer, T., P. Sehr and M. Pawlita. 2006. Suppression of Non-Specific Binding in Serological Luminex Assays. Journal of Immunological Methods 309:200-204. Doi:http://dx.doi.org/10.1016/ j.jim.2005.11.008.

Whitlock, G. C., D. M. Estes and A. G. Torres. 2007. Glanders: Off to the Races with Burkholderia mallei. Microbiology Letters 277:115-122. Doi:http://dx.doi.org/10.1111/j.15746968.2007.00949.x.

Wiśniewski, J. R., A. Zougman, N. Nagaraj and M. Mann. 2009. Universal Sample Preparation Method for Proteome Analysis. Nature Methods 6:359-362. Doi:10.1038/nmeth.1322.

Welker, F., M. J. Collins, J. A. Thomas, M. Wadsley, S. Brace, E. Cappellini, S. T. Turvey, M. Reguero, J. N. Gelfo, A. Kramarz, J. Burger, J. Thomas-Oates, D. A. Ashford, P. D. Ashton, K. Rowsell, D. M. Porter, B. Kessler, R. Fischer, C. Baessmann, S. Kaspar, J. V. Olsen, P. Kiley, J. A. Elliott, C. D. Kelstrup, V. Mullin, M. Hofreiter, E. Willerslev, J. Hublin, L. Orlando, I. Barnes and R. D. E. MacPhee. 2015. Ancient Proteins Resolve the Evolutionary History of Darwin's South American Ungulates. Nature advance online publication. doi:10.1038/ nature14249

Wolverton, S. 2013. Data Quality in Zooarchaeological Faunal Identification. Journal of Archaeological Method and Theory 20:381-396. Doi:10.1007/ s10816-012-9161-4.

Wolverton, S., J. Dombrosky and A. Barker. 2014. Paleoetnobiologia. In Introdução À Etnobiologia, edited by U. P. Albuquerque, pp. 43-51, NUPEEA, Recife.

\section{Biosketches}

Andrew Barker is a PhD candidate at the University of North Texas studying archaeological residues, omics, and the effects of environmental contaminants on aquatic organisms.

Jonathan Dombrosky is a PhD student at the University of New Mexico studying the paleozoology of north central and central New Mexico during late prehistory.

Dale Chaput is a PhD candidate in the Department of Cellular Biology, Microbiology, and Molecular Biology at the University of South Florida investigating APPdependent mechanisms in neurodegeneration using mass spectrometry. 